\title{
滨海城市岸线利用方式转型与空间重构 巴塞罗那的经验
}

The Transformation and Spatial Reconstruction of Shoreline Utilization in Coastal City: The Case of Barcelona

程鹏

Cheng Peng

摘要: 以港城空间关系演变为线索, 回顾了巴 塞罗那滨海岸线发展历程的三个阶段。重点分 析和评价了巴塞罗那滨海岸线的利用方式与功 能格局、公共设施与开放空间、交通体系、景 观体系和岸线设计等空间发展要素与格局。一 方面, 解读其发展历程有助于我们认识滨海岸 线利用的阶段特征; 另一方面, 关于空间发展 要素与格局的解读对于我们适时开展滨水地区 规划实施评价、塑造地方特色等具有启发性。

Abstract: Based on the evolution of the spatial relation of the port and the city, this paper reviews the three stages of the development of Barcelona coast, then analyzes the elements of Barcelona coastal shoreline and the spatial development pattern, including shoreline utilization and function pattern, public facilities and open space, traffic system, landscape system and shoreline design. On one hand, interpreting the development process can help us understand the utilization stage characteristics of the coastal shoreline; on the other hand, interpreting the elements and patterns of spatial development is very instructive for us to carry out evaluation of the planning and implementation of waterfront area shape of local identity.

关键词: 滨海城市; 岸线利用; 空间重构; 巴塞罗那

Keywords: Coastal City; Shoreline Utilization; Space Reconstruction; Barcelona

作者: 程鹏, 同济大学建筑与城市规划学院城市 规划系, 博士研究生。tjhasen@163.com

\section{引言}

滨海岸线是滨海城市发展的重要依托, 在滨海城市发展的各个阶段, 滨海岸 线的利用方式和滨水区域的空间格局呈现出差异化的阶段性特征。1950 年代一 1960 年代, 伴随着后工业时代的经济转型和船舶大型化等交通发展趋势, 港城 关系调整和滨水地区再开发率先在北美和欧洲等城市兴起 ${ }^{[1]}$ 。1 1990 年代以来, 滨 水地区再开发开始受到国内学者关注, 研究主要聚焦在国外案例引介和规划方法 建构方面 ${ }^{[2.7]}$; 滨水地区再开发的规划和实践更是大量展开。对于滨海城市的岸线 利用和滨水空间设计, 相关学者主要对海口、三亚、厦门和青岛等滨海城市进行 了研究和解读 ${ }^{[8.11]}$ 。总体上, 围绕滨海城市岸线利用的议题, 既有研究表明, 无 论是相对宏观的港城空间关系演变还是滨水地区空间发展具体要素的优化, 各个 城市均呈现出一定的共性特征和差异化特点。就港城空间关系而言, 从1960年 代伯德（Bird）首次提出港口发展六阶段模型到近年来诺特伯姆（Notteboom） 提出港口发展三阶段模型 ${ }^{[12,13]}$, 港口发展的阶段理论不断拓展和修正, 进而揭示 了港城空间关系演变较具普遍性的阶段性特征, 而各个城市在资源条件和发展路 径上的差异, 又使得港城关系的时空发展格局呈现出一定的个性化特点。对于 面向后工业时代使用需求的滨水区域空间重构, 针对交通、功能、公共空间和 生态文化等要素, 形成了可达性、混合性、公共性和亲水性、延续性等共识性 原则 ${ }^{[5-7]}$, 保护和塑造城市滨水区域的个性特色更成为诸多城市的共同追求。自 上海浦东开发起, 国内城市大规模的滨水地区规划建设和再开发已进行 20 余 年, 目前这一进程仍方兴未艾; 同时大众对于滨水空间的需求日益提高, 而滨水 空间普遍缺乏地方特色等问题也日益显现, 探索岸线资源的适时合理利用方式、 优化滨水区域与城市空间的整体协调关系、塑造滨水区域空间特色仍具有重要的 现实意义。

巴塞罗那于 1980 年代开始实施 “城市向大海开放” (Open the City to the Sea）的发展构想, 通过 1992 年奥运会、2004 年世界文化论坛等大事件, 推动了 滨海岸线利用和城市空间结构的优化 ${ }^{[14]}$, 使得滨海地区的城市公共生活日益丰富, 成为独具魅力的旅游目的地和城市形象窗口。国内对于巴塞罗那城市更新的成功 经验已有一定的研究成果, 主要涉及城市发展历程、城市更新政策与特定地区实 践 ${ }^{[15-17]}$ 等方面, 缺乏对于滨海地区空间发展要素与格局的详细解读。为此, 本文 
拟聚焦巴塞罗那滨海岸线利用和滨水空间格局的分析与评 价, 以期在空间分析与实施评价方面积累一定的研究基础。

\section{1 港城关系发展历程}

自古以来, 地中海在将巴塞罗那塑造为一个开放、多元 民族和文化交融的城市中扮演了重要角色, 港口与城市的空 间关系贯穿了城市发展的不同阶段, 成为影响城市乃至区域 发展的重要因素。总体上, 巴塞罗那的港口发展经历了三个 阶段, 即布局、拓展和专业化阶段 ${ }^{[13]}$, 引导了巴塞罗那城市 空间结构的演变 ${ }^{[18]}$ (图 1, 图 2)。

\section{1 历史的荣光和与大海的隔绝}

巴塞罗那位于伊比利亚半岛东北部, 城市背靠科塞罗拉 山 (Collserola), 面朝地中海, 主体位于贝索斯河 (Besós) 和布莱加特河 (Llobregat) 之间的丘陵地带。自公元前 5 世 纪到公元前 1 世纪, 历经迦太基人和罗马人的争夺, 由罗马

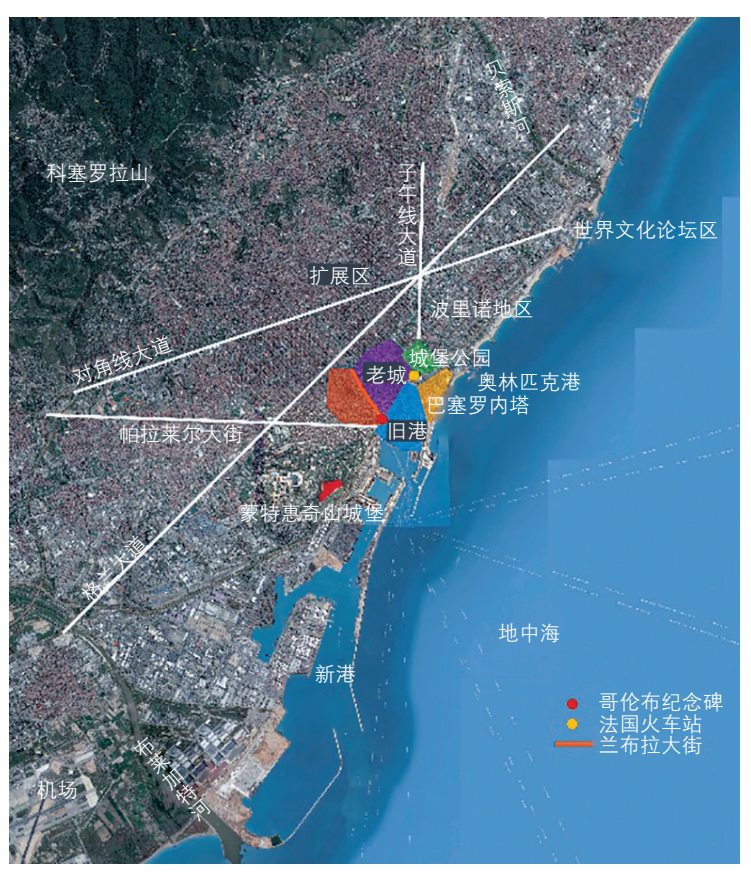

图 1 巴塞罗那城市空间要素图 资料来源 : 根据参考文献 [18] 及相关资料整理
人建立了紧邻海岸线的防御性城市, 构成了今天巴塞罗那老 城哥特区的雉形。随后, 历经西哥特人、摩尔人、法兰克人 统治, 于 12 世纪并人阿拉贡王国, 1469 年阿拉贡王室与卡 斯蒂利亚王室联姻, 合并形成了今天西班牙的主体。在此期 间, 城市随着王国在地中海的扩张而增长, 在老城的西侧建 立了新城, 共同形成了六边形的城市轮廓, 新城与旧城之间 的河流改造成为通向港口的交通要道, 也就是今天的兰布拉 大街 (La Rambla)。在兰布拉大街连接巴塞罗那旧港（Port Vell) 的交汇处, 真立着 1888 年万国博览会时所建高达 $60 \mathrm{~m}$ 的哥伦布纪念碑, 以纪念 1493 年哥伦布第一次从美洲 探险凯旋。巴塞罗那正是费迪南国王和伊莎贝拉女王欢迎哥 伦布凯旋的地方, 而哥伦布纪念碑也时刻提醒着人们这座地 中海城市与大海的不解之缘。

从城市与港口的关系来看, 出于安全考虑, 巴塞罗那城 市空间始终与海岸线保持着一定距离, 港口作为城市的门户, 两者的空间关系相对独立。14 世纪后城市建设开始突破旧 城向滨海岸线区域发展, 如今地处巴塞罗那旧港的航海博物 馆和莱埃塔那大街 (Via Laietana) 端头的广场就是曾经的皇 家造船厂和商品交易所。但随后由于受政治上的打压被禁止 与海外交往, 巴塞罗那作为港口城市的地位下降, 1493 年 的哥伦布凯旋成为大航海时代巴塞罗那最后的荣光。

18 世纪, 巴塞罗那在西班牙内战后遭受了长期的经济、 政治和文化压迫。在马德里中央政府的高压下, 城市建设被 牢牢限制在新建的城墙范围内; 同时, 为监视和控制城内 居民, 在老城东面的高地上建设了一处八边形的军事堡垒, 也就是今天城堡公园的所在地 ${ }^{[19]}$ 。至此, 巴塞罗那的城市 空间再一次与大海隔绝, 唯一邻近海岸线的建设是城墙外 的巴塞罗内塔区 (Barceloneta), 由于军事堡垒的建设和港 口发展需要, 大量的渔民、工人和水手搬迁至此处邻近港 口的区域。

\section{2 大海在城市的背面}

进人工业化时代, 巴塞罗那成为西班牙重要的工业城市, 1854 年拆除城墙后, 城市向外扩展。1 860 年通过的塞尔达 (Cerdà) 方案制定了巴塞罗那城市扩展区的发展框架, 规
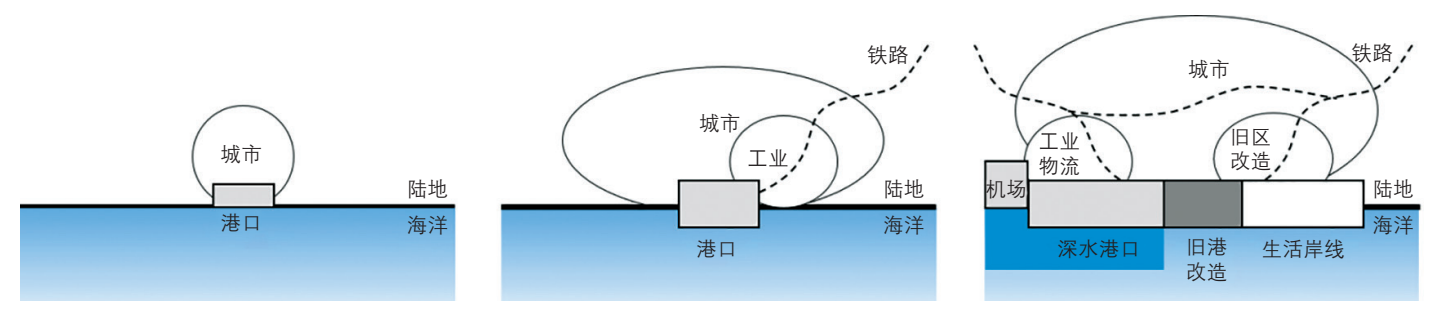

图 2 巴塞罗那的港城关系演变图 资料来源 : 作者绘制 
则化网格的扩展区发展格局既突破了传统城市格局的制约, 又完整保护了巴塞罗那老城格局, 提供了一个开放的具有适 应性的城市生长空间。规划合理地回应了工业化时代对城市 空间公平性的诉求, 以及铁路、公路等新的运输方式的发展, 引导了城市建设应对文化、社会和技术发展的新需求, 其方 格路网加对角线道路的几何格局一直延续至今天。

在城市与海岸的关系处理上, 塞尔达通过道路的组织 将城市与海岸联系起来。首先规划一条与海岸线平行、与 蒙特惠奇山 (Montjuic) 呈切线的格兰大道 (Gran Via), 其 余规划道路与之平行或垂直相交, 形成一个完整的方格路 网铺满整个扩展区; 为削减过于理性主义的纯方格路网设 计, 规划一条与方格路网斜交的对角线大道 (Diagonal), 建立一条从高地到海岸的连续线; 同时, 通过子午线大道

(Meridiana) 定义城市南北向, 帕拉莱尔大街（Parallel） 定义城市东西向, 两条道路延伸至港区, 延长线垂直相交 于巴塞罗那旧港 ${ }^{[20]}$ (图 1)。

然而, 尽管城市道路体系考虑了与海岸线的关系, 但滨 海地区仅仅是塞尔达规划所考虑的次要因素。在工业化时代 经济大发展背景下, 1848 年, 西班牙开通的第一条铁路通向 巴塞罗那旧港, 也就是今天的法国火车站 (Estació de Fran), 滨海岸线的港口区域交通枢纽功能得以强化。城市东北扩展 区的波里诺（Poblenou）地区在靠近滨海岸线区域集聚了大 量的工厂、仓库等设施和人口急剧增长后形成的居住区。城 市建设虽逐渐沿海岸线展开, 但由于空间拓展是由内陆向海 岸延伸, 加之滨水区域污染严重、环境恶劣, 大海成了城市 的背面 ${ }^{[21]}$ 。巴塞罗那在 1888 年和 1929 年举办了两届万国博 览会, 举办地分别在城堡公园和蒙特惠奇山区域, 海岸利用 仍局限在巴塞罗那旧港区域。

\section{3 城市向大海开放}

1975 年, 弗朗哥的独裁统治结束; 1979 年, 巴塞罗那 第一个民选市政府诞生。此时的巴塞罗那一方面面临着自 1950 年代工业经济快速发展以来产生的环境污染、人口膨 胀和基础设施建设滞后等问题 ; 另一方面伴随着经济逐步向 后工业化转型, 波里诺地区因产业逐步向外转移而日益衰落, 城市内部及滨海岸线一带的环境品质亟待改善。

1986 年巴塞罗那被选为 1992 年奥运会举办城市, 在城 市向大海开放的目标下, 政府将奥运场馆等设施分散布置在 城市的四个建设片区。其中, 奥运主场馆布局在紧邻滨海地 区的蒙特惠奇山, 奥运村和奥林匹克港选址在波里诺地区滨 海地带。在滨海的陆域地区通过拆除沿海铁路线、环城快速 路局部人地、延伸城市道路至滨海地区等方式强化了滨海区 域的交通可达性 ; 建设商业娱乐设施和住宅楼在奥运会期间
作为运动员驻地, 奥运会后成为面向城市中产阶级的滨海居 住区; 沿滨海岸线建设奥林匹克港和新的海滩, 奥运会期间 作为水上项目比赛区域, 奥运会后成为游艇码头和公共开放 的海滩。在此期间启动了巴塞罗那旧港和巴塞罗内塔区的改 造, 将原先封闭管理的货港改建成为城市滨海休闲娱乐中 心 ${ }^{[22]}$, 并在其西南建设了新的深水港口, 巴塞罗内塔区也 沿滨海大道建设了新的海滩。

奥运会后, 结合 2004 年举办的世界文化论坛, 把城市 向大海开放的发展目标延伸至城市东北角的贝索斯河人海口 区域。围绕论坛的活动主题, 延伸城市的主轴线对角线大道 至海边, 实现了塞尔达建立从高地到海岸连续线的规划设想, 大道与海岸交汇处便是世界文化论坛主场馆区域。通过改造 利用该区域原有的发电站、垃圾和废水处理厂等基础设施, 增加会议中心、酒店、游艇码头和大学校园等城市功能, 建 设滨海广场、公园、步道等公共空间, 实现了该区域与西南 部城市滨海岸线区域在交通和功能上的衔接, 并在会后成为 城市的一个新中心 ${ }^{[23]}$ 。

结合奥运会和世界文化论坛等大事件改造和开发城市滨 海岸线区域, 使得滨海区域成为城市重要的公共开放空间, 巴塞罗那整个城市第一次真正面向大海, 成为地中海首屈一 指的滨海旅游城市。滨海岸线区域的开发成为自塞尔达方案 以来巴塞罗那城市结构最大的一次调整。

\section{2 岸线利用与功能重组}

\section{1 适宜性一一岸线利用优化}

滨海岸线是滨海城市发展过程中典型的稀缺资源, 根据 滨海城市发展的阶段性特征, 岸线功能的适宜性应成为合理 利用岸线资源的首要原则。随着港城关系的调整, 巴塞罗那 滨海岸线的利用方式也经历了转型发展, 遵循深水深用、浅 水浅用的原则, 顺应了后工业时代交通运输方式的转型和城 市消费空间的发展需求。

按照滨海岸线主导功能类型, 可以将巴塞罗那滨海岸 线划分为生产性岸线和生活性岸线。生产性岸线分布在巴 塞罗那旧港以南至布莱加特河之间的区域。该区域背靠蒙 特惠奇山, 邻近巴塞罗那机场, 以港口功能为主, 前沿水 深 8 14 m, 港内现有商业码头线总长约 $12 \mathrm{~km}$, 水域面积 $300 \mathrm{hm}^{2}$, 包括杂货、散货和集装箱码头。生活性岸线包括 巴塞罗那旧港至贝索斯河人海口之间的区域。该区域海岸 线直线长度约 $6 \mathrm{~km}$, 岸线平直, 水深较浅, 包括旧港休闲 娱乐中心、巴塞罗内塔生活及度假休闲区、奥林匹克港和 世界文化论坛区, 以及镶嵌其间的 9 块总长度达 $4.5 \mathrm{~km}$ 的 公共开放海滩和 1 处硬质驳岸的浴场, 是城市居民和旅游 度假人群共享的公共滨海岸线（图 3)。 


\section{2 耦合性一一用地功能重组}

滨海岸线是滨海城市空间结构的重要组成部分, 滨海区 域的用地功能格局应与滨海岸线利用方式相协调, 统筹兼顾 陆域和水域发展。以 1980 年代巴塞罗那旧港改造和奥林匹 克港选址建设为起点, 巴塞罗那每一段滨海岸线的利用方式 转型都伴随着其陆域腹地区域用地功能的重组, 腹地功能与 岸线利用相匹配有效衔接了滨海岸线与城市主体, 使得城市 活动与城市肌理向滨海岸线区域延续。

总体上, 随着巴塞罗那新港朝城市南部的深水方向发 展, 港城关系的演变塑造了巴塞罗那城市空间结构的新格局。 以蒙特惠奇山为界, 南部的生产性岸线以摩洛特海岸 (the Litoral Morrot）为起点直至布莱加特河, 与巴塞罗那机场隔 河相望。大规模深水港口的新建带动了巴塞罗那铁路运输网 络的整体南移, 港口、机场、铁路编组站等区域性交通设施 在南部区域汇集, 使得这片陆域腹地快速发展为城市新兴的 工业物流区域。摩洛特海岸另一端靠近巴塞罗那旧港区域的 邮轮码头和轮渡是港口和城市的过渡区域 ${ }^{[24]}$ 。北部的生活性 岸线以旧港为起点, 其陆域腹地是巴塞罗那主要的城市生活 功能区域, 有着良好的生活配套和旅游服务设施, 连续的生 活性公共开放岸线及其背靠的城市生活功能区域形成了巴塞 罗那独具特色的滨海岸线公共休闲带。

滨海岸线公共休闲带大致可以分为三段, 每一段滨海岸 线与其背靠的城市生活功能区域在功能布局和发展的时空格
局上均存在相当的耦合关系（图 3, 表 1)。旧港和巴塞罗内 塔转型成为生活及度假休闲区, 其背靠的老城区和城堡公园 是巴塞罗那历史遗迹和旅游景点最集中的区域, 其中旧港通 过兰布拉大街连接老城哥特区, 成为巴塞罗那最具历史感和 活力的地方。紧邻奥林匹克港及城市沙滩的是传统老工业区 波里诺地区, 自 2000 年波里诺地区改造计划 (MMPG) 实 施以来, 环境改善和设施建设推动了传统工业向知识密集型 经济的转型发展。贝索斯河人海口区域的游艇俱乐部、新巴 塞罗那海洋动物园（规划）和浴场背靠的则是由世界文化论 坛带动发展的城市综合功能新中心。

\section{3 开放空间与公共设施}

\section{1 公共性一一开放空间体系}

滨海岸线是滨海城市天然的开放空间, 确保滨海岸线 的公共性是城市居民和游客共同享有这一开放空间的基本保 证。巴塞罗那的生活性岸线利用避免了私有化的封闭性和内 向型特点, 充分体现了公共性和共享性, 不仅确保了滨海岸 线在空间上的贯通和开放空间体系的完整性，也充分发挥了 滨海岸线的社会价值，大量的人流为滨海区域带来了生机与 活力。

巴塞罗那生活性岸线区域的开放空间主要包括沙滩浴 场、游艇码头、公园绿地和道路广场等类型。其中, 9 块向 公众开放的沙滩构成了开放空间的主体，约占生活性岸线

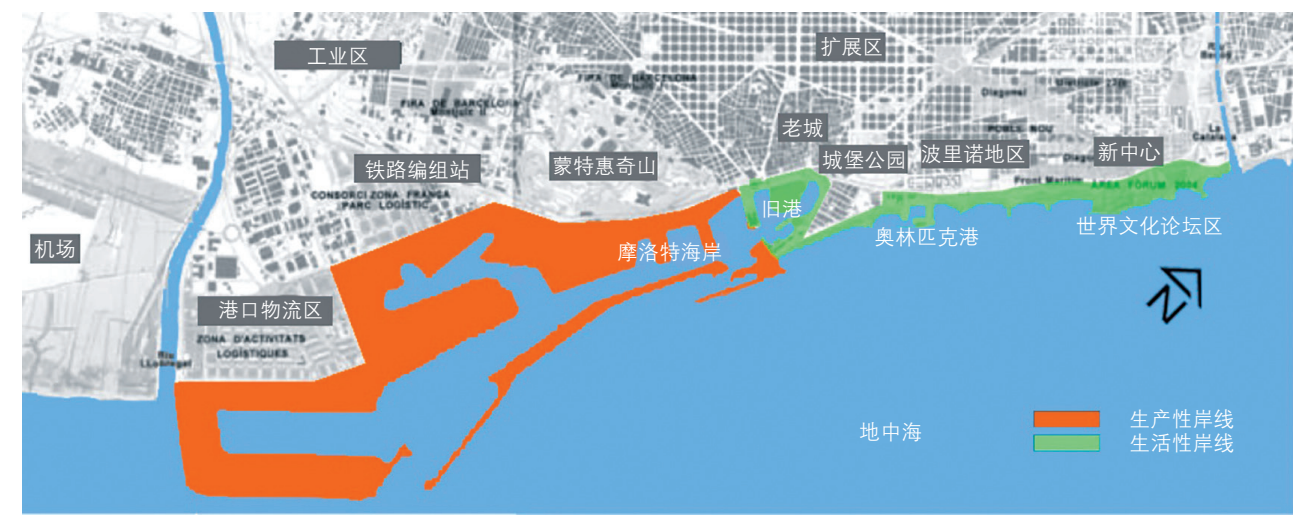

图 3 巴塞罗那滨海岸线分布与功能格局

资料来源 : 根据参考文献 [18] 及相关资料整理

表 1 巴塞罗那滨海岸线与腹地功能一览表

\begin{tabular}{|c|c|c|c|}
\hline \multicolumn{2}{|r|}{ 岸线区域 } & \multicolumn{2}{|r|}{ 腹地区域 } \\
\hline 生产性岸线 & 港口 & 工业物流 & \\
\hline \multirow{3}{*}{ 生活性岸线 } & 旧港与巴塞罗内塔区域 & 老城区与城堡公园 & 包括哥特区、拉巴尔区和海岸区, 是巴塞罗那历史遗迹和旅游景点最集中的区域 \\
\hline & 奥林匹克港及城市沙滩 & 奥运村与波里诺地区 & 22@ 计划、老工业区向知识密集型活动区域转型 \\
\hline & 贝索斯河人海口区域 & 城市新中心 & $\begin{array}{l}\text { 世界文化论坛、市政基础设施改造并打造由会议中心、酒店、大学、动物园（规划）、 } \\
\text { 住宅等构成的城市综合功能区域 }\end{array}$ \\
\hline
\end{tabular}

资料来源：作者整理 
总长度的四分之三, 在世界文化论坛区设有一处硬质驳岸 的海水浴场; 游艇码头共有 3 处，包括旧港区域的邮轮和 游艇码头、奥林匹克港和世界文化论坛区游艇码头 ; 公园 绿地包括巴塞罗内塔公园、波里诺公园、加西亚法利亚街 道绿化、对角线大道公园、滨海公园和海洋动物园 (规划) 等, 与旧港、巴塞罗内塔和世界文化论坛区域的各类广场 及滨海大道相连接, 在海岸和城市之间形成了相互渗透的 开放空间 (图 4)。

此外, 紧邻滨海岸线的第一排建构筑物保持充分的建筑 退界也是确保开放空间体系完整性的重要因素。从开放空间 的人气与活力来看, 世界文化论坛区域显然不及南侧的旧港 和奥林匹克港区域, 这与该区域最晚开发有关, 但也应注意 到尺度对于公共空间质量的影响。与众多新区的发展过程一 样, 太大、太高、太快的发展建设使得该区域的空间尺度不 如其他区域亲切宜人。

\section{2 多元性一一公共设施体系}

滨海岸线与城市用地的交界地带是一个复杂的区域，在 滨海岸线向城市休闲和消费空间转型过程中, 能否发展成为
具有活力的城市区域是评价转型成功与否的重要标准。巴塞 罗那的滨海岸线如今充满活力, 完成了从以港口和工业为主 的单一功能区域向多元功能的城市活力区域的转型。多元化 的公共设施体系是良好的空间环境之外吸引城市居民和游客 的又一重要因素, 包括滨海岸线公共休闲带的多元业态和沙 滩浴场完善的配套设施。

在滨海岸线公共休闲带, 多元化的公共设施主要集中在 两个区域 : 从旧港至奥林匹克港的滨海区域和世界文化论坛 区域的城市新中心。1985-1992 年, 通过迁移铁路、拆除高墙、 梳理交通等措施, 使得旧港成为人人可以进人的滨水公共空 间，政府和私营企业合资陆续修建了购物中心、水族馆、历 史博物馆、世界贸易中心和酒店等大型公共建筑 ${ }^{[22]}$; 而奥林 匹克港区域在奥运会结束后仍聚集了大量酒店、办公楼、餐 厅和商店, 加之巴塞罗内塔区域的大学、住宅、酒店和餐厅 等功能, 使得该地区成为各种功能高度混合的区域, 老城的 公共生活得以向滨海岸线地区延续。在世界文化论坛区域的 城市新中心, 则集聚了会议中心、文化中心、会展中心、购 物中心、大学、办公楼和酒店、游乐场等公共设施, 提升了 整个东北部滨海岸线区域的活力（图 5)。

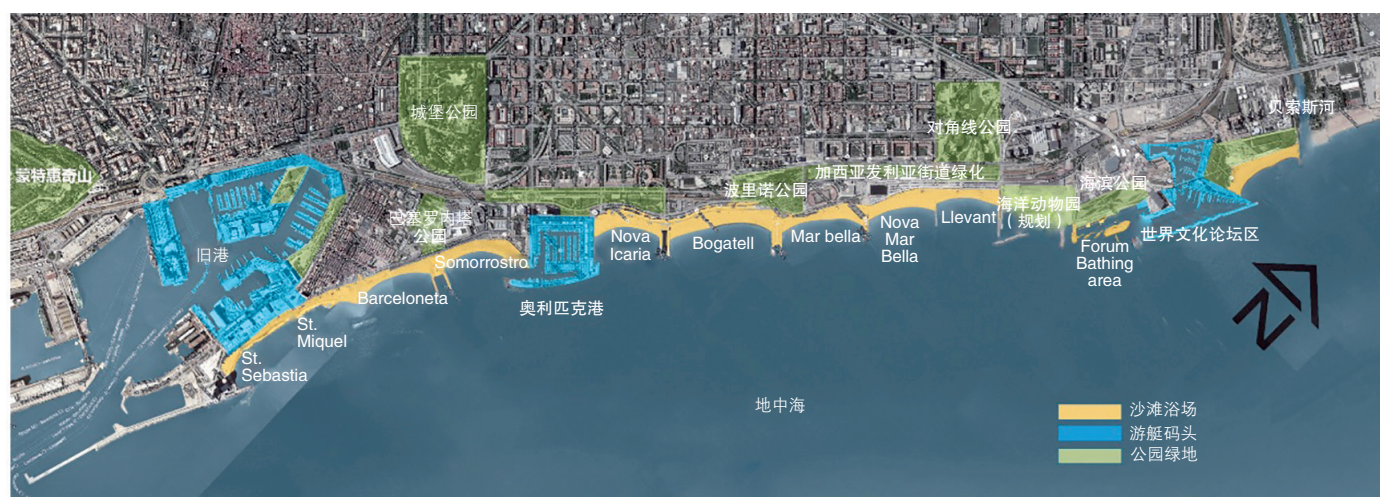

图 4 滨海岸线区域开放空间体系 资料来源 : 根据参考文献 [25] 绘制

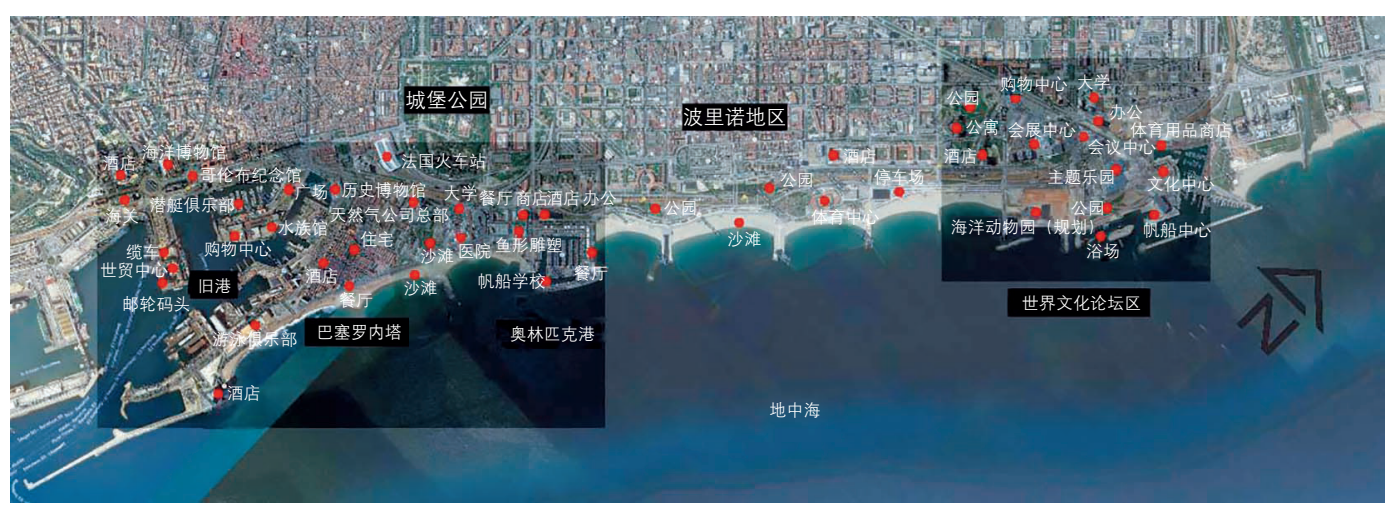

图 5 滨海岸线区域主要的业态分布 资料来源 : 作者基于谷歌影像图绘制 
温和的地中海气候意味着巴塞罗那的海滩一年四季均 可使用, 但主要的游泳季节一般在 5 月中旬一 9 月中旬。公 共部门为保证公众安全和健康、保护环境, 从圣塞巴斯蒂亚

(Sant Sebastià) 到莱万特 (Llevant) 之间超过 $4.5 \mathrm{~km}$ 长的 城市海滩均设有为游泳和其他活动服务的公共设施。而在其 他季节则仅开放海滩综合管理计划办公室和巴塞罗内塔、索 莫罗斯特罗 (Somorrostro) 和博加特尔 (Bogatell) 三处海滩 的公共卫生间, 不提供救生服务。以巴塞罗内塔海滩为例, 这个海滩是巴塞罗内塔区域 4 块海滩中的一块, 位于圣米克 尔 (Sant Miquel) 和索莫罗斯特罗海滩之间, 长度 $422 \mathrm{~m}$, 平均宽度约 $79 \mathrm{~m}$, 是巴塞罗那历史最悠久、最受游客和青 少年欢迎的地方, 其完善的服务设施和服务项目为人们游玩 和举办各种活动提供了极大的便利 ${ }^{[25]}$ (图 4, 表 2)。

\section{3 可达性一一道路交通体系}

滨海岸线与城市特殊的空间关系, 要求强大的道路交通 体系扩展到这一城市边缘区域, 以保证滨海区域良好的可达 性, 支撑富有生机的多样化活动。工业时代遗留下来与海岸 线平行的铁路, 以及环城快速路构成了巴塞罗那城市与海岸
线之间巨大的障碍, 通过一系列改善道路交通体系的措施, 巴塞罗那成功缝合了城市与海岸线之间的裂痕, 也延续了传 统城市肌理格局。

一方面, 随着深水港口的南移, 巴塞罗那拆除了北部 生活性岸线区域的沿海铁路线; 而对于必须保留的环城快速 路, 则采取了立体交通的方式, 在人流量较大的旧港、奥林 匹克港和波里诺公园区域快速路入地, 在世界文化论坛区 域整体抬高地面跨过了快速路, 其他路段则采用了道路上 跨快速路的方式。由此, 大量与海岸线垂直的道路得以跨 过交通障碍通向海岸线, 延续了塞尔达方案奠定的城市肌 理格局, 同时建设了相当数量的停车场, 引人了多条公共 交通线路, 大大提升了滨海区域的交通可达性（图 6)。另 一方面, 在化解过境交通与内部交通矛盾的基础上, 滨海 岸线区域慢行交通的连续性和舒适性也成为重要的考量因 素, 连续的滨海道路串联了整个开放空间体系, 道路的断面 和尺度设计适应了大量慢行交通需求, 通过压缩机动车交 通空间, 扩大步行道和非机动车道宽度, 越是慢行的交通 方式越靠近滨海一线布置, 使得慢行交通占据了主导地位 (图 7)。

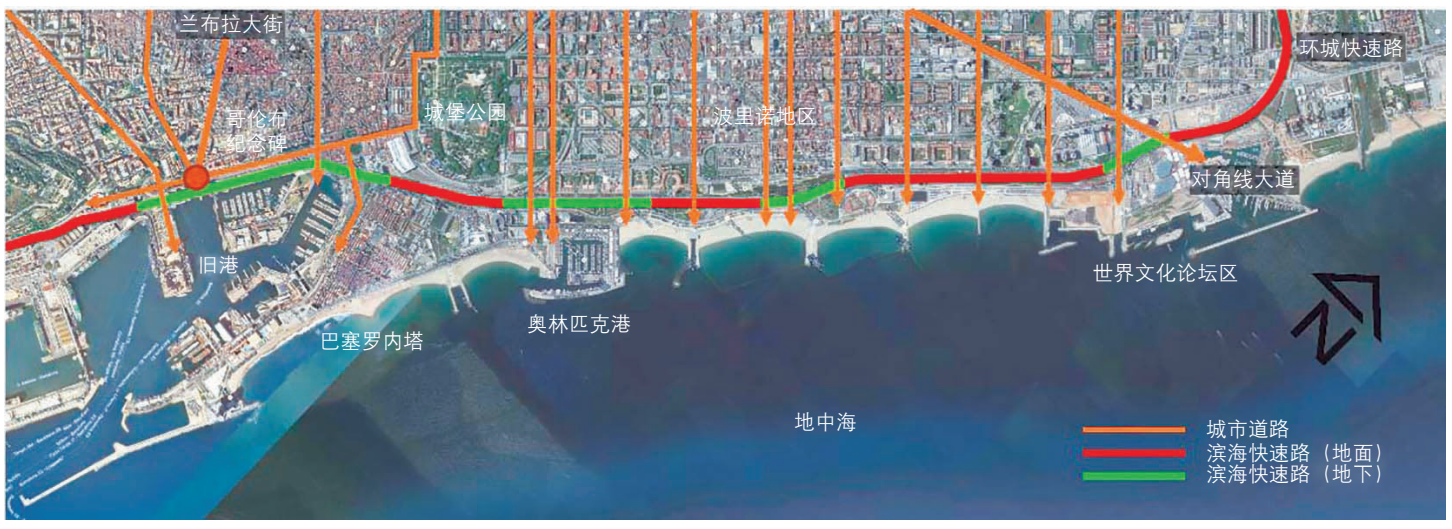

图 6 环城快速路在滨海区域的立体处理方式 资料来源 : 作者基于谷歌影像图绘制

表 2 巴塞罗内塔海滩服务设施与服务项目一览表

\begin{tabular}{|c|c|}
\hline 服务类型 & 设施与服务项目 \\
\hline \multirow{4}{*}{ 交通 } & 公交: 10、14、16、17、36、39、40、45、51、57、59、64 \\
\hline & 地铁：L4, 巴塞罗内塔和休达德亚 (Ciutadella) 站 \\
\hline & 电车：T4, 休达德亚一维拉港奥运村站（Ciutadella-Vila Olimpica） \\
\hline & 公共自行车 : 巴塞罗内塔和安德里亚多里亚 (Andrea Dòria) 滨海长廊（布鲁加达 [Brugada] 广场前） \\
\hline \multirow{2}{*}{ 停车 } & 无障碍停车场 \\
\hline & 自行车停车场 \\
\hline 设备 & $\begin{array}{l}\text { 无障碍公共则所、无障碍浴室、残疾人士助浴区、有浮标的防波堤和浴场、救生员塔和椅子、公共则所、浴室、喷泉、垃圾箱和回收箱、儿童游戏区、 } \\
\text { 排球场、公共广播系统、公用电话、储物柜、人行桥 }\end{array}$ \\
\hline 服务 & 餐厅、体育装备、遮阳伞出租、躺椅出租、自行车出租、无线网络等 \\
\hline 信息和服务点 & 急救和救援 \\
\hline
\end{tabular}

资料来源 : 参考文献 [25] 


\section{4 景观体系与岸线设计}

\section{1 层次性一一滨海景观格局}

滨海岸线一般为线性空间, 视线开敞, 兼具自然和人工 景观的特点, 有利于营造远近高低各不同的丰富景观层次, 往往使其成为滨海城市中景观最美、最具特色的区域。“山一 海一城” 历来是巴塞罗那最重要的景观要素, 随着城市向大 海开放, 也重塑了城市的整体景观格局, 滨海景观愈加成为 巴塞罗那城市意象的主导因素。

巴塞罗那对于建筑高度有着严格的控制要求, 城市旧 区中建筑以多层为主, 圣家族大教堂、阿格巴大厦（Agbar Tower）等高层建筑屈指可数。近年来, 在对角线大道尽端 远离城市旧区的新中心逐渐林立起一簇高层建筑群。在处理 滨海岸线与山体、城市的景观格局方面, 控制视线通廊是一 个重要的手段。巴塞罗那整体较低的建筑高度保护了山体景 观和历史风貌格局, 城市背靠的科塞罗拉山与海岸线之间鲜 有视线遮挡物, 站在奎尔公园 (Park Güell) 便可俯瞰整个城 市和海岸线, 而紧邻海岸线的蒙特惠奇山可近距离欣赏繁忙 的港口和一望无际的大海, 连接港口与蒙特惠奇山的空中缆 车更是在海岸线与山体之间建立了直接联系 ; 垂直于海岸线 的数条街道则建立了城市与海岸线之间的视线通廊, 其中兰 布拉大街在哥伦布纪念碑附近宽度有所增加，既便于疏解大 规模的人流, 又放大了视域, 提升了远眺旧港的视觉效果。 在塑造滨海城市天际线方面, 巴塞罗那以多层建筑为主的较 为整齐平缓的天际线构成了海天之间的基本轮廓, 局部点缀 的几处标志型高层建筑打破了天际线的单调格局, 构成了滨 海天际线的视觉中心。滨海岸线区域的标志性建筑包括真立 在旧港最外围的巴塞罗那 W 酒店、奥林匹克港象征着大门
的两栋高层塔楼和盖里设计的鱼形雕塑、西班牙天然气公司 总部大楼, 以及对角线大道尽端城市新中心的高层建筑群, 具有较强的识别性 (图 8, 图 9)。从滨海岸线沿线的视点来 看, 尽管巴塞罗那生活性岸线较为平直, 但在港口、沙滩等 区域局部的凹凸变化, 大大丰富了欣赏滨海界面景观的视点; 而以多层建筑为主, 辅以小尺度的公共建构筑物和绿化景观, 既在整体上保证了开放空间的舒展性, 又在局部景观上给人 尺度宜人的亲切感。

\section{2 亲水性一一滨海岸线设计}

滨海岸线区域承载了城市居民和游客大量的游憩行为, 人们的亲水需求不仅局限在对大海远观的视觉和听觉感受, 更要求舒适宜人的亲水环境能提供近距离、直观的触觉感受, 这就要求滨海岸线具体的空间形态设计处理好安全与亲水的 矛盾。针对不同岸线的区位, 以及与城市腹地的关系, 巴塞 罗那采用了不同的岸线处理方式, 呈现出不同的景观格局和 亲水体验性。

横向上, 从贝索斯河到布莱加特河, 巴塞罗那的整个海 岸线都经历了人工化改造, 处理方式包括软质沙滩和硬质驳 岸两种类型, 近年来对于生态和景观系统的恢复扩展至河口 并上溯到河流沿线区域 ${ }^{[26]}$ 。为满足港口码头的防潮防浪和生 产需要, 旧港以南所有的生产性岸线均采用了硬质驳岸的处 理方式。旧港、奥林匹克港和世界文化论坛区域同样采用了 硬质驳岸的处理方式, 但结合防波堤、延伸至水面的平台、 栈桥等设计手法，通过折线、凹凸等方式丰富了亲水空间界 面, 塑造了宁静的亲水环境氛围。9 块人工塑造的软质沙滩 形态呈曲线, 水深较浅, 流线型岸线不仅确保了水体的自然 流畅, 也塑造了海滩环境的动感与活力。

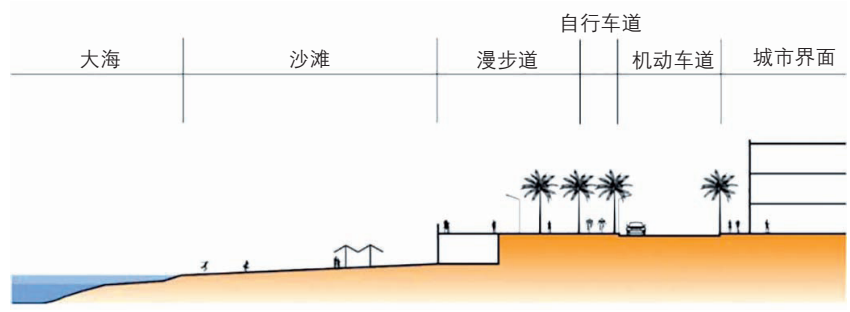

图 7 典型滨海道路横断面图 资料来源：作者绘制
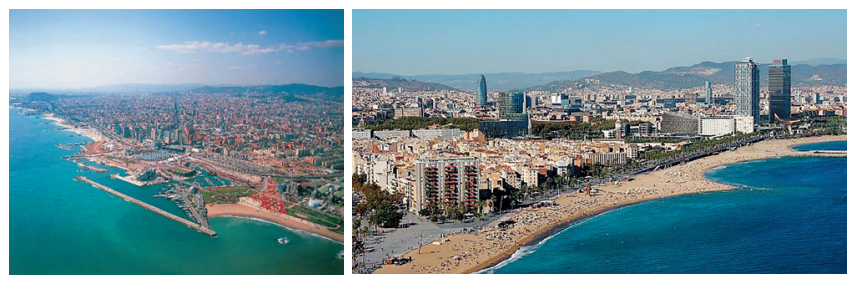

图 9 从地中海看巴塞罗那的滨海天际线

资料来源 : 左图源自参考文献 [21] ; 右图源自 http://www.barcelona.cat/sites/default/files panoramica_redaccio_4.jpg

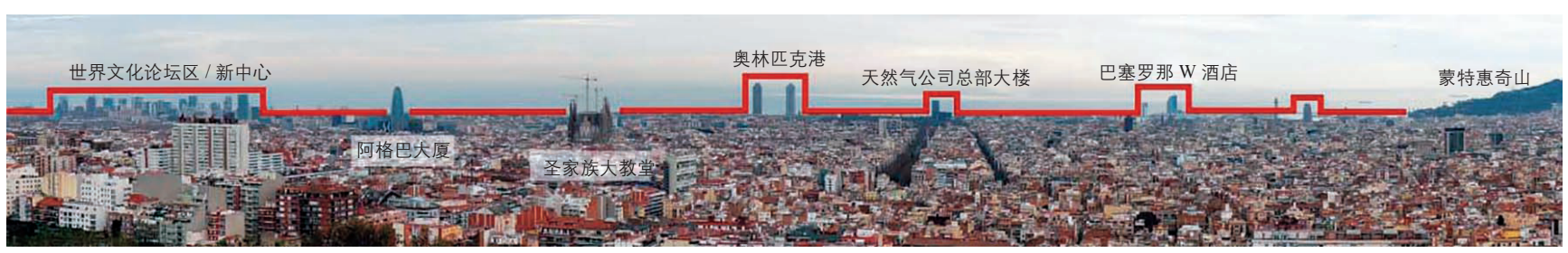

图 8 从奎尔公园看巴塞罗那的滨海天际线 资料来源 : 作者拍摄并绘制 
纵向上, 为满足防灾要求, 一是在近海区域设置了防波 堤, 包括沙滩外围一般没于水下的防波堤; 二是结合滨海道 路沿海岸线建设了防潮堤, 防潮堤与海平面之间采用多样化 的断面处理方式。在旧港的硬质驳岸区域, 多采用亲水平台 和台阶式驳岸方式; 在世界文化论坛区域, 坚向高差较大, 采用了分级平台的驳岸方式。在几处公共海滩区域, 竖向的 高差处理更为直观, 堤岸与沙滩分为两层, 之间用坡道或台 阶连接, 堤岸上方为观景平台, 下方空间日常作为沙滩的服 务区域, 较好地化解了高差对于景观和亲水行为的阻隔。

\section{5 结语}

滨海岸线是滨海城市独具特色的稀缺资源, 港口作为滨 海岸线利用的重要方式, 其动态演化过程不仅是地理和物质 空间的变迁, 更是技术进步、国际贸易与产业发展格局演变 的现实反映。从港城空间关系演变来看, 巴塞罗那的港城关 系呈现出港口城市普遍经历过的阶段性和动态性特征, 在港 口发展的不同阶段, 都很大程度地直接影响了城市空间结构 的演变。以深水港口建设为契机, 统筹布局铁路、机场等区 域重大交通基础设施, 带动陆域地区整体发展无疑具有借鉴 意义。显然, 影响港城关系发展的新因素仍会不断出现, 有 效把握各类新因素可能带来的影响, 对于合理调整港口功能、 优化滨海城市空间格局至关重要。

滨海岸线的利用方式不仅仅局限在港口码头等交通和生 产功能, 尤其是 20 世纪中后期以来, 城市滨水地区再开发 推动了滨海岸线的利用方式向休闲娱乐、文化商业等综合性 的生活功能转变。伴随巴塞罗那滨海岸线利用方式转型的是 整个滨海岸线地区的物质空间更新和经济发展方式转型。作 为滨海城市发展的核心资源, 滨海岸线在不同的发展阶段以 不同的方式吸引着城市发展要素的集聚, 进而影响城市的竞 争力 ${ }^{[27]}$ 。巴塞罗那以大事件为契机推动岸线利用方式的渐进 式转型、岸线与腹地功能的耦合、需求导向下的人性化空间 和设施体系, 以及城市整体和岸线区域的景观控制和特色塑 造, 均是滨海城市岸线利用方式转型与空间重构值得借鉴的 成功经验。同时应意识到, 巴塞罗那的滨海区域转型发展有 其局限性, 一方面, 成功的滨海岸线资源再开发仅是城市转 型发展的重要因素之一, 城市的发展得益于诸多资源要素的 共同推动; 另一方面, 滨海岸线新开发区域存在尺度过大和 亲水性不足的问题, 但该区域仍处在转型发展过程中, 随着 功能和空间的调整完善将不断得以优化。

对同一城市而言, 如何针对不断变化的发展需求, 持续 利用好滨海岸线这一独特资源, 将成为推动城市可持续发展 的一个长期的重要议题; 对于不同城市而言, 不同的岸线资 源条件和发展轨迹, 既可借鉴其他城市的成功经验, 也应寻
求自身独特的发展逻辑, 塑造具有地方特色的城市滨水空间。 而诸如本文对于巴塞罗那滨海岸线地区发展的基本要素、空 间格局和结构体系进行适时的分析和评价, 应成为大量滨水 地区规划实施后的重要工作。UP

\section{参考文献}

[1]王建国, 吕志鹏.世界城市滨水区开发建设的历史进程及其经验 [J]. 城 市规划, 2001(7): 41-46.

[2] 张庭伟. 滨水地区的规划和开发 [J]. 城市规划, 1999(2): 49-54.

[3] 张杰. 伦敦码头区改造一一后工业时期的城市再生 [J]. 国外城市规划, 2000(2): 32-35.

[4] 刘雪梅, 保继刚. 国外城市滨水区再开发实践与研究的启示 [J]. 现代城 市研究, 2005(9): 15-26.

[5] 黄翼.城市滨水空间的设计要素 [J]. 城市规划, 2002(10): 68-72.

[6] 钱欣. 城市滨水区设计控制要素体系研究 [J]. 中国园林, 2004(11): 31-36.

[7] 杨保军, 董珂. 滨水地区城市设计探讨 [J]. 建筑学报, 2007(7): 7-10.

[8] 张谦益。海港城市岸线利用规划若干问题探讨 []]. 城市规划, 1998(2): $50-52$.

[9]王建国，方立，陈宇，等、海口滨海岸线城市设计探索 [J]. 规划师， 2003(9): 41-45.

[10] 幸克威, 黄丹丹. 厦门东南滨海岸线规划设计评析 [J]. 福建建筑, 2010(1): 28-31.

[11] 蔵珊, 奕峰。滨海岸线利用方式与城市发展及布局的关系—以三亚 和青岛为例 $[C] / /$ 中国城市规划学会. 城市时代, 协同规划-2013 中国城市规划年会论文集 (03-城市总体规划). 2013: 9 .

[12] BIRD J H. The major seaports of the United Kingdom[M]. Hutchinson, 1963.

[13] NOTTEBOOM T E, RODRIGUE J P. Port regionalization: towards a new phase in port development[J]. Maritime Policy \& Management, 2005, 32(3): 297-313.

[14] 沙永杰, 董依. 巴塞罗那城市滨水区的演变 [J]. 上海城市规划, 2009(1): 56-59.

[15] 李翅. 巴塞罗那的城市文化与城市空间发展策略初探 [J]. 国外城市规 划, 2004(4): 67-71.

[16] 黄琲斐.巴塞罗那的城市更新 [J]. 建筑学报, 2002(5): 57-61.

[17] 范建红。公共政策导向下的城市滨水区再利用一以巴塞罗那为例 [J]. 中外建筑, 2014(6): 57-59.

[18] MARSHALL T. Transforming Barcelona[M]. London and New York: Routledge, 2004.

[19] 杨猛. 巴塞罗那扩展区——政治与城市空间的演义 [J]. 室内设计, 2009(6): 47-51.

[20] BUSQUETS J, 鲁安东, 薛云婧. 城市历史作为设计当代城市的线 索——巴塞罗那案例与塞尔达的网格规划 [J]. 建筑学报, 2012(11): 2-16.

[21] Ajuntament de Barcelona. 22@Barcelona, the Innovation District[EB/ OL]. (2012-12-30)[2016-07-18]. http://www.22barcelona.com/ documentacio/22bcn_1T2010_eng.pdf.

[22] 刘和, 卜菁华.从货物港到休闲娱乐中心一重建巴塞罗那 VELL 港 的启示 [J]. 规划师, 2004(3): 52-54.

[23] MONCLÚS F J. The Barcelona model: and an original formula? from 'reconstruction' to strategic urban projects (1979-2004)[J]. Planning Perspectives, 2003, 18(4): 399-421.

[24] 高远. 摩洛特海岸规划 [J]. 城市建筑, 2015(4): 84-91.

[25] Ajuntament de Barcelona. Bathing and Beaches[EB/OL]. (2017-12-31)[201803-06]. http://www.barcelona.cat/en/what-to-do-in-bcn/bathing-and-beaches.

[26] 高远. 贝索斯河公园环境恢复规划 [J]. 城市建筑, 2015(4): 38-43.

[27] 孙施文, 王吉. 城市滨水区发展与城市竞争力关系研究 [J]. 规划师, 2004(8): 5-9.

(本文编辑: 张祎娴) 